\title{
DETEKSI IMUNOGLOBULIN MIU (IgM) DAN IMUNOGLOBULIN GAMMA (IgG) PADA PENDERITA DEMAM TIFOID
}

\author{
Nurdin ${ }^{1}$, Andi Tendry Julianti ${ }^{2}$ \\ 1,2 Jurusan Analis Kesehatan Poltekkes Makassar
}

Koresponden : nurdinanalis@gmail.com, 081343837651

\begin{abstract}
ABSTRAK
Demam tifoid merupakan penyakit infeksius yang disebabkan oleh bakteri Salmonella tiphi. Penegakkan diagnosis demam tifoid adalah hal yang penting terutama agar diagnosis ditegakkan lebih tepat dan pengobatan dapat diberikan lebih cepat. Seiring perkembangan teknologi dalam ilmu kesehatan diagnosis demam tifoid dapat dilakukan untuk mendeteksi infeksi melalui pemeriksaan antibodi $\operatorname{IgM}$ dan $\operatorname{IgG}$, dimana antibodi ini mempunyai makna dalam diagnosa yaitu agar mengetahui fase infeksi ada penderita demam tifoid dengan menggunakan tes imunokromatografi. Selain memiliki spesifitas dan sensitivitas yang tinggi tes imunokromatografi juga mudah dilakukan dan tidak memerlukan peralatan khusus untuk interpretasi hasil. Jenis penelitian ini adalah deskriptif yang bertujuan untuk mengetahui gambaran antibodi IgM dan IgG pada penderita demam tifoid yang terdiagnosis oleh klinisi. Teknik pengambilan sampel adalah purposive sampling dengan jumlah 30 sampel. Analisa data dilakukan dengan mengumpulkan hasil pemeriksaan antibodi IgM dan IgG pada sampel penderita demam. Setelah dilakukan analisa data, didapatkan hasil pemeriksaan positif IgM sebanyak 2 sampel (6,7\%) menunjukkan fase awal infeksi, positif IgG sebanyak 2 sampel $(6,7 \%)$ menunjukkan infeksi ulang sebelumnya, positif IgM dan IgG sebanyak 14 sampel (44,6\%) menunjukkan fase tengah infeksi dan 12 sampel (40\%) menunjukkan tidak adanya antibodi $\operatorname{IgM}$ dan IgG. Tenaga klinisi disarankan sebaiknya melakukan pemeriksaan antibodi IgM dan IgG meskipun telah melakukan pemeriksaan uji widal, agar dapat mengetahui fase infeksi sehingga diagnosis dapat ditegakkan dengan tepat dan pengobatan diberikan dengan cepat.
\end{abstract}

\section{Kata Kunci : Demam Tifoid, Antibodi IgM, Antibodi IgG}

\section{PENDAHULUAN}

Demam tifoid merupakan penyakit infeksius yang disebabkan oleh bakteri Salmonella typhi. Penyebaran dapat terjadi melalui makanan atau air yang terkontaminasi. Setelah bakteri Salmonella typhi dimakan atau diminum, kuman akan berkembang biak dan menyebar ke dalam aliran darah dan saluran usus. Gejala termasuk demam tinggi berkepanjangan, kelelahan, sakit kepala, mual, sakit perut, dan sembelit 
atau diare. Beberapa pasien mungkin memiliki ruam. Kasus yang parah dapat menyebabkan komplikasi serius atau bahkan kematian. Demam tifoid dapat dikonfirmasi melalui tes darah (WHO, 2018)

Departemen Kesehatan RI pada tahun 2008 menjelaskan bahwa di Indonesia hampir seluruh Provinsi ada kejadian tifoid. Situasi penyakit demam tifoid di Provinsi Sulawesi Selatan pada tahun 2014 yaitu suspek penyakit typhus tercatat sebanyak 23.271 sedangkan penderita demam tifoid sebanyak 16.743 penderita, dengan kasus tertinggi yaitu di Kabupaten Bulukumba (3.270 kasus), Kota Makassar (2.325 kasus), Kabupaten Enrekang (1.153 kasus) dan terendah di Kabupaten Toraja (0 kasus), Kabupaten Luwu (1 kasus), dan di Kabupaten Tana Toraja (19 kasus). (Dinkes, 2015).

Penegakkan diagnosis demam tifoid adalah hal yang penting terutama agar diagnosis ditegakkan lebih tepat dan pengobatan dapat diberikan lebih cepat. Diagnosa untuk demam tifoid dapat dilakukan yaitu dengan menggunakan metode deteksi kultur dan tes antibodi menggunakan uji widal. Namun, metode kultur tidak memiliki kecepatan, fasilitas kultur kurang dan terbatas di banyak wilayah. Selain itu, uji widal menggunakan serum dengan teknik agglutinasi untuk diagnosis demam tifoid tidak spesifik untuk mendeteksi infeksi Salmonella typhi. Seiring perkembangan teknologi dalam ilmu kesehatan diagnosa demam tifoid dapat dilakukan untuk mendeteksi antibodi $\operatorname{IgM}$ dan $\operatorname{IgG}$, dimana antibodi ini mempunyai makna dalam diagnosa yaitu agar mengetahui fase infeksi pada penderita demam tifoid dengan menggunakan tes imunokromatografi. Selain memiliki spesifitas dan sensitivitas yang tinggi tes imunokromatografi juga mudah dilakukan, dan tidak memerlukan peralatan khusus untuk interpretasi hasil.

Respon imun yang khas dimulai dengan peningkatan antibodi IgM terhadap antigen yang menstimulasi (imunogen). Fase ini diikuti dengan produksi antibodi IgG terhadap antigen tersebut. Stimulasi berulang dengan antigen tersebut mengakibatkan produksi IgG yang lebih besar tetapi dengan waktu yang lebih pendek setelah stimulus antigenik yang berhasil. (Sacher RA,Richarda M, 2004)

Secara umum, kadar antibodi IgM yang bermakna terhadap suatu virus, bakteri atau agen infeksius lain diinterpretasikan sebagai bukti adanya infeksi akut, sedangkan kadar IgG spesifik yang tinggi konsisten dengan persistensi imunitas pada fase konvalesen setelah infeksi terdahulu. Saat menafsirkan tes, deteksi IgM positif ditafsirkan sebagai penyakit tifoid akut (fase awal infeksi) sedangkan deteksi igG dan IgM positif ditafsirkan sebagai penyakit tifoid akut (pada fase tengah infeksi) dan IgG positif ditafsirkan adanya infeksi ulang sebelumnya. Kuman tifoid dapat berasal dari karier demam tifoid yang merupakan sumber penularan yang sukar diketahui karena mereka tidak menunjukkan gejala-gejala sakit.

Di daerah yang sangat endemis dimana tingkat penularan tifoid tinggi, deteksi IgG spesifik akan meningkat, karena IgG dapat bertahan lebih dari 2 
tahun setelah infeksi tifoid, deteksi IgG spesifik tidak dapat dibedakan antara kasus akut dan pemulihan. Sehingga diperlukan untuk melakukan pemeriksaan untuk mendeteksi IgM.

\section{METODE}

Penelitian ini bersifat deskriptif, Lokasi penelitian ini dilaksanakan di Puskesmas Jongaya dilaksanakan pada bulan Juni-Juli tahun 2018.

Populasi dalam penelitian ini adalah semua pasien penderita demam tifoid yang terdiagnosis oleh klinisi di Puskesmas Jongaya. Sampel penelitian ini adalah pasien penderita demam tifoid oleh Salmonella typhi. Spesimen penelitian ini menggunakan serum penderita demam tifoid. Besar sampel yang digunakan dalam Penelitian ini adalah 30 sampel. Teknik pengambilan sampel pada penelitian ini adalah purposive sampling yaitu penderita demam tifoid yang melakukan pemeriksaan widal. Serum penderita demam tifoid dideteksi mengunakan tes cepat immunokromatografi. Tes ini memiliki spesifitas $99.3 \%$ dan sensitivitas 92.9\%. (Koczula, KM, Andrea G. 2016).

\section{Langkah-langkah penelitian}

Pra Analitik: Alat yang digunakan pada pemeriksaan ini adalah pengatur waktu, tempat sampel, dan pipet. Bahan yang digunakan adalah buffer, serum, kaset tes QDx S.typhi IgG/IgM.

Analitik : Ditulis identitas pasien pada kaset tes, diteteskan sebanyak 2 tetes atau 501 serum pada lubang sampel, kemudian ditambahkan 1 tetes buffer (hindari gelembung udara) pada lubang yang sama. Setelah itu, dibaca hasil dalam 10 menit.
Berdasarkan latar belakang di atas, maka penulis tertarik untuk melakukan penelitian untuk mendeteksi antibodi IgG dan IgM pada penderita demam tifoid.

Pasca Analitik : Munculnya garis berwarna pada garis control dan garis IgM dan IgG menandakan adanya fase tengah infeksi, munculnya garis berwarna pada garis control dan garis IgG menandakan adanya infeksi ulang atau pembawa kronis, munculnya garis berwarna pada garis control dan garis IgM menandakan adanya fase awal infeksi. Hasil negatif hanya terdapat garis pada control dan invalid apabila tidak terdapat garis pada control.

Pengolahan dan analisis data

Data yang diperoleh dari hasil penelitian disajikan dalam bentuk tabel lalu dihitung menggunakan rumus persentasi lalu dideskripsikan menggunakan narasi.

Rumus persentasi : $\operatorname{IgG} / \operatorname{IgM}: \frac{x}{N} \times 100 \%$ Ket : $x$ : Jumlah IgG/IgM positif, $N$ : Jumlah sampel

\section{HASIL}

Hasil pemeriksaan antibodi IgM dan IgG pada penderita demam tifoid. Dari 30 sampel terdapat hasil pemeriksaan yang menunjukkan hasil positif IgM sebanyak 2 sampel $(6,7 \%)$, hasil positif IgG sebanyak 2 sampel $(6,7 \%)$, hasil positif $\operatorname{IgM}$ dan $\operatorname{IgG}$ sebanyak 14 sampel (46,66\%), dan hasil negatif $\operatorname{IgM}$ dan $\operatorname{IgG}$ sebanyak 12 sampel $(40 \%)$. 
Tabel 1. Gambaran antibodi IgM dan IgG pada penderita demam tifoid di Puskesmas Jongaya

\begin{tabular}{ccccc}
\hline No. & $\begin{array}{c}\text { Kode } \\
\text { Sampel }\end{array}$ & $\begin{array}{c}\text { Jenis } \\
\text { Kelamin }\end{array}$ & Umur & Hasil Pemeriksaan Antibodi \\
\hline $\mathbf{1}$ & A & L & 27 & Positif IgM dan IgG \\
\hline $\mathbf{2}$ & B & L & 7 & Negatif \\
\hline $\mathbf{3}$ & C & L & 15 & Positif IgM dan IgG \\
\hline $\mathbf{4}$ & D & L & 1 & Negatif \\
\hline $\mathbf{5}$ & E & L & 27 & Negatif \\
\hline $\mathbf{6}$ & F & L & 29 & Negatif \\
\hline $\mathbf{7}$ & G & P & 42 & Negatif \\
\hline $\mathbf{8}$ & H & P & 23 & Negatif \\
\hline $\mathbf{9}$ & I & P & 42 & Positif IgG \\
\hline $\mathbf{1 0}$ & J & L & 8 & Negatif \\
\hline $\mathbf{1 1}$ & K & P & 49 & Positif IgM dan IgG \\
\hline $\mathbf{1 2}$ & L & L & 24 & Positif IgM dan IgG \\
\hline $\mathbf{1 3}$ & M & P & 17 & Negatif \\
\hline $\mathbf{1 4}$ & N & P & 46 & Positif IgM dan IgG \\
\hline $\mathbf{1 5}$ & O & P & 18 & Positif IgM dan IgG \\
\hline $\mathbf{1 6}$ & P & L & 23 & Positif IgM \\
\hline $\mathbf{1 7}$ & Q & P & 27 & Positif IgM dan IgG \\
\hline $\mathbf{1 8}$ & R & P & 21 & Positif IgM dan IgG \\
\hline $\mathbf{1 9}$ & S & L & 52 & Positif IgM dan IgG \\
\hline $\mathbf{2 0}$ & T & L & 12 & Positif IgM dan IgG \\
\hline $\mathbf{2 1}$ & U & L & 6 & Negatif \\
\hline $\mathbf{2 2}$ & V & L & 7 & Negatif \\
\hline $\mathbf{2 3}$ & W & L & 7 & Negatif \\
\hline $\mathbf{2 4}$ & X & L & 6 & Negatif \\
\hline $\mathbf{2 5}$ & Y & P & 52 & Positif IgM dan IgG \\
\hline $\mathbf{2 6}$ & Z & P & 17 & Positif IgM \\
\hline $\mathbf{2 7}$ & AA & P & 12 & Positif IgG \\
\hline $\mathbf{2 8}$ & AB & P & 21 & Positif IgM dan IgG \\
\hline $\mathbf{2 9}$ & AC & P & 27 & Positif IgM dan IgG \\
\hline $\mathbf{3 0}$ & AD & P & 29 & Positif IgM dan IgG \\
\hline & s & Pag & \\
\hline
\end{tabular}

Sumber : Data Primer, 2018

\section{PEMBAHASAN}

Penentuan jenis antibodi pada penderita demam tifoid penting untuk menentukan kriteria pasien dan berdampak pada pengobatan. Kementrian Kesehatan RI pada tahun 2006 menjelaskan terapi antimikrobial dengan kloramfenikol masih menjadi pilihan utama, berdasarkan efiksasi dan 
harga. Namun cukup sering menimbulkan carrier dan reinfeksi. Reinfeksi biasanya berlangsung tidak lama, dan diberikan antibiotik yang sama, namun dengan penggunaan kloramfenikol kejadian relaps ini justru makin meningkat. Bila penderita dengan riwayat pernah terinfeksi tifoid serta memiliki predisposisi untuk carrier maka pengobatan pertama adalah golongan quinolone. Quinolone efektif mencegah relaps dan carrier. Carrier akan terjadi bila penderita tidak diobati atau pengobatan yang tidak adekuat. Reinfeksi juga terjadi sehubungan dengan pengobatannya tidak adekuat, baik dosis atau lama pemberian antibiotik.

IgM anti-Salmonella merupakan antibodi fase akut yang muncul akibat adanya infeksi Salmonella typhi. Antibodi ini muncul sebagai respon tubuh terhadap adanya antigen asing dalam tubuh manusia. Sedangkan antibodi IgG adalah antibodi sekunder, yaitu antibodi yang dibentuk setelah beberapa hari infeksi dan dapat bertahan lama walau penderita telah sembuh. IgM disebut sebagai antibodi fase akut karena muncul pada saat infeksi baru terjadi atau sedang terjadi. IgM anti-Salmonella bisa dideteksi pada hari ke-5 untuk infeksi primer dan hari ke-2 untuk infeksi sekunder. Untuk daerah endemis seperti di negara kita ini, kecepatan deteksi ini sangat penting mengingat kebanyakan kasus adalah infeksi sekunder, dimana tes Widal kurang dapat membedakan mana kasus yang benar-benar tifoid atau bukan. Tes Widal membutuhkan dua kali pemeriksaan dalam rentang waktu satu minggu yang dapat memperlambat penanganan, sedangkan hasil IgM antiSalmonella sudah bisa positif dalam waktu 2 hari infeksi saja

\section{KESIMPULAN}

Berdasarkan hasil penelitian yang dilakukan terhadap 30 sampel maka dapat disimpulkan bahwa :

1. Gambaran antibodi IgM pada penderita demam tifoid didapatkan sebanyak 2 sampel $(6,7 \%)$ menunjukkan fase awal infeksi.

2. Gambaran antibodi IgG pada penderita demam tifoid didapatkan 2 sampel (6,7\%) menunjukkan infeksi yaitu infeksi ulang sebelumnya.

3. Gambaran antibodi $\operatorname{IgM}$ dan $\operatorname{IgG}$ pada penderita demam tifoid didapatkan sebanyak 14 sampel $(44,6 \%)$ menunjukkan fase tengah infeksi

4. Hasil negatif $\operatorname{IgM}$ dan $\operatorname{IgG}$ sebanyak 12 sampel (40\%) menunjukkan tidak adanya infeksi Salmonella typhi.

\section{SARAN}

Berdasarkan kesimpulan diatas maka penulis memberikan saran yaitu, sebaiknya tenaga klinisi melakukan pemeriksaan antibodi IgM dan IgG meskipun telah melakukan pemeriksaan uji widal, agar dapat megetahui fase infeksi sehingga diagnosis dapat ditegakkan dengan tepat dan pengobatan diberikan dengan cepat. 


\section{UCAPAN TERIMAKASIH}

Kami banyak mengucapkan terimakasih kepada semua pihak yang telah berjasa dalam penelitian ini terutama kepada Ketua jurusan Analis kesehatan poltekkes Makassar, kepala puskesmas Jongaya Makassar dan kepala laboratoium PKM Jongaya serta semua pihak yang tidak bias disebutkan satu-satu.

\section{DAFTAR PUSTAKA}

Baratawidjaja, Karnen Garna \& Iris Rengganis. 2012. Imunologi Dasar Edisi 10. Jakarta: FKUI

Brush, John L. 2018. Typhoid fever. diakses 10 April 2018. [http://www.Medicine.Mexcap e.com/Article/231135-

Overview\#24]

Handojo, I. 2004. Imunoasai terapan pada beberapa penyakit infeksi.
Surabaya: Airlangga University Press

Kemenkes RI, 2006. Pedoman pengendalian demam tifoid. Diakses 02 Agustus 2018. [http://www.pdpersi.co.id/perat uran/kepmenkes/kmk3642006. pdf]

Koczula, KM, Andrea G. 2016. Lateral flow assays. Diakses 31 Mei 2018.

[https://www.ncbi.nlm.nih.gov/ pmc/articles/PMC4986465/]

Sacher, Ronald A \& Richarda Mcpherson. 2004. Tinjauan klinis hasil pemeriksaan Lab $11^{\text {th }}$ ed. Jakarta:EGC

WHO. 2018. Typhoid. diakses 26 Mei 2018.

[http://www.who.int/newsroom/factsheets/detail/typhoid]. 